\title{
Pitfalls in the Evaluation of Uric Acid as a Risk Factor for Vascular Disease
}

\author{
Konstantinos Tziomalos ${ }^{1}$, Vasilios G. Athyros ${ }^{2}$, Asterios Karagiannis ${ }^{2}$ and Dimitri P. Mikhailidis*,1 \\ ${ }^{I}$ Department of Clinical Biochemistry (Vascular Prevention Clinic), Royal Free Hospital Campus, University College \\ Medical School, University College London (UCL), London, UK \\ ${ }^{2}$ Second Propedeutic Department of Internal Medicine, Aristotle University, Hippokration Hospital, Thessaloniki, \\ Greece
}

\begin{abstract}
The association between serum uric acid (SUA) levels and the risk for vascular disease is controversial. Several studies in the general population suggested that elevated SUA levels are independently related to increased vascular morbidity and mortality. However, in other studies this relationship was not significant when other vascular risk factors were considered. Some evidence also suggests that uric acid might be implicated in the development of hypertension, renal disease and insulin resistance. We review the epidemiological data on the relationship between SUA levels and vascular disease and summarize the potential adverse vascular effects of uric acid. We also discuss the associations of SUA levels with established vascular risk factors and the potential benefits of lowering SUA concentration. It is unclear whether uric acid is a causal risk factor for vascular disease. Until more conclusive data are available, patients with elevated SUA levels should be evaluated for the presence of more established risk factors (including type 2 diabetes mellitus, metabolic syndrome and chronic kidney disease) and treatment should be targeted against these factors.
\end{abstract}

Keywords: Uric acid, vascular risk, hypertension, chronic kidney disease, coronary heart disease.

\section{INTRODUCTION}

The association between serum uric acid (SUA) levels and the risk for vascular disease is controversial [1]. Several studies in the general population suggested that elevated SUA levels are independently related to increased vascular morbidity and mortality [2, 3]. However, in other studies this relationship was not significant when other vascular risk factors were considered $[4,5]$.

We review the epidemiological data on the relationship between SUA levels and vascular disease and summarize the potential adverse vascular effects of uric acid. We also discuss the associations of SUA levels with established vascular risk factors and the potential benefits of lowering SUA levels.

\section{SEARCH METHODS}

A literature search (using PubMed) was performed using the following key words: "uric acid", "coronary heart disease", "cardiovascular disease", "morbidity", "mortality", "risk", "hypertension", "chronic kidney disease", "insulin resistance" and "allopurinol" up to 10 March 2009. The authors also manually reviewed the references of retrieved articles for any pertinent material.

*Address correspondence to this author at the Department of Clinical Biochemistry, Royal Free Hospital Campus, University College Medical School, University College London (UCL), Pond Street, London NW3 2QG, UK; Tel: +44 207830 2258; Fax: +44 207830 2235;

E-mail: MIKHAILIDIS @aol.com

\section{EPIDEMIOLOGICAL DATA}

In cross-sectional studies, patients with established coronary heart disease (CHD) had higher SUA levels [6]. However, other studies did not report an independent association between SUA levels and the presence of CHD [7]. SUA levels were also associated with the presence and extent of coronary artery calcification (a surrogate measure of coronary atherosclerosis) in patients with the metabolic syndrome (MetS) [8]. Nevertheless, this association was not observed in patients without MetS [8] or in patients with family history of hypertension [9]. In some prospective studies in the general population, elevated SUA levels were associated with higher risk for CHD morbidity and mortality $[2,3]$. In contrast, SUA levels were not independent predictors of CHD events in a nested case-control study within the prospective Reykjavik study [10]. In the Framingham study, SUA levels were not independently associated with CHD events in women [4]. In men, SUA levels were inversely associated with the incidence of CHD [4]. In several studies including only men, SUA levels were not independently associated with CHD events [5, 6, 11-13]. In contrast, in a large study in 28,613 elderly women (mean age 62.3 years) followed-up for a median of 15.2 years, SUA levels were associated with increased CHD mortality [14]. In a metaanalysis of 16 prospective studies in the general population (9,458 CHD cases and 155,084 controls), elevated SUA levels were independently associated with CHD events in both genders [10]. However, this association was non-significant in the 8 studies who adjusted more completely for confounders [10]. 
In the general population, SUA levels did not correlate independently with carotid atherosclerosis in some studies [15] whereas in others a correlation was observed only in men [16]. In prospective studies, elevated SUA levels were associated with higher risk for fatal and non-fatal ischemic stroke in the general population $[2,11]$, in elderly subjects $[14,17,18]$ and in patients with type 2 diabetes mellitus (T2DM) [19]. However, an analysis of the Atherosclerosis Risk in Communities (ARIC) study confirmed this association only in patients who were not treated with diuretics [20]. In another study in 9,125 men, low and not elevated SUA levels were associated with stroke mortality [12].

In a cross-sectional study, SUA levels were higher in patients with peripheral arterial disease (PAD) [21]. However, in an analysis of the Multiple Risk Factor Intervention Trial (MRFIT), SUA levels were not independently associated with incident PAD [22].

In prospective studies in the general population, higher SUA levels were independently associated with vascular mortality in some reports $[3,13,23]$ but not in all $[4,5]$.

In patients with established CHD, elevated SUA levels independently predicted all cause mortality in some [24] but not all studies [25]. In patients who had a stroke, elevated SUA levels also predicted a worse outcome [26-30]. However, other studies reported that SUA levels were inversely associated with neurological impairment or death in patients with stroke [31]. The potential role of uric acid in the pathogenesis of stroke was recently reviewed elsewhere [32].

Heart failure (HF) is associated with elevated SUA levels [33-35]. In addition, SUA levels directly correlate with the severity of HF $[34,36]$. The excessive activation of xanthine oxidase $(\mathrm{XO})$ in the failing myocardial cell might partly explain these changes [37, 38]. Decreased renal excretion of uric acid and increased XO substrate resulting from enhanced ATP breakdown might also play a role [37, 38]. Some studies suggested that elevated SUA levels are independently associated with greater risk for heart transplantation and mortality in patients with HF [39-41].

\section{ADVERSE VASCULAR EFFECTS OF ELEVATED SUA LEVELS}

In vitro studies showed that uric acid stimulates the production of the pro-inflammatory chemokine monocyte chemoattractant protein-1 (MCP-1) from rat vascular smooth muscle cells (VSMC) [42]. Uric acid also induced the production of C-reactive protein (CRP) from human VSMC and endothelial cells [43]. In animal studies, repeated administration of uric acid stimulated the synthesis of tumor necrosis factor- $\alpha(\mathrm{TNF} \alpha)$ [44]. In the general population, SUA levels correlated with high sensitivity CRP (hsCRP) levels [13, $45,46]$ and with circulating levels of interleukin-6 (IL-6) and TNF $\alpha$ [46]. In addition, subjects with elevated SUA levels had higher risk of experiencing an increase in hsCRP and IL6 levels [47].

In vitro studies showed that uric acid can also stimulate rat and human VSMC proliferation and migration [43, 4850]. Interestingly, atherosclerotic plaques contain more uric acid than normal arteries [51].

In vitro studies showed that uric acid reduces the release of nitric oxide (NO) from human and bovine endothelial cells $[43,52]$. In animal models, experimental hyperuricemia was associated with a fall in circulating NO levels [52]. In healthy subjects, SUA and NO levels vary during the day in a reciprocal pattern [53]. SUA levels negatively correlated with endothelium dependent vasodilation (EDV), an index of endothelial function $[54,55]$. Impaired EDV was reported in patients with hyperuricemia $[56,57]$. However, experimental infusion of uric acid in healthy subjects did not affect EDV [58]. In another study, infusion of uric acid improved EDV in patients with type 1 diabetes mellitus and in smokers [59].

SUA levels negatively correlated with arterial stiffness in healthy adults [55] and in stroke survivors [60]. Arterial stiffness is associated with higher vascular risk [61]. However, experimental infusion of uric acid did not affect arterial elasticity [58].

Uric acid is an important contributor to serum antioxidant activity [62, 63]. Experimental administration of uric acid increased serum antioxidant activity and attenuated the intense physical exercise-induced oxidative stress [64, 65]. However, in vitro studies showed that uric acid can also have pro-oxidant properties [66-68].

\section{ASSOCIATION OF SUA LEVELS WITH VASCULAR RISK FACTORS}

\section{a. Uric Acid and Hypertension}

In the general population, SUA levels correlate with blood pressure (BP) $[3,11,13,69,70]$ and are higher in hypertensive patients [3]. Elevated SUA levels were independently associated with carotid atherosclerosis in some studies in hypertensive patients [71] but not in other [72]. SUA levels were associated with increased risk for vascular events in both hypertensive men and women [73-75]. However, in the Losartan Intervention For Endpoint reduction in hypertension (LIFE) study, SUA levels were associated with vascular events only in women [76]. In the Systolic Hypertension in Europe (Syst-Eur) trial, SUA levels did not predict vascular events in either gender [77]. In another study, the relation of SUA levels with vascular morbidity and mortality was Jshaped in both genders, with the nadir in the second quartile [78]. Uric acid was also a stronger risk factor for myocardial infarction and stroke in normotensive subjects than in hypertensive patients [2].

Preclinical and observational data suggest that uric acid might play a role in the development of hypertension [79]. In animal models, experimental hyperuricemia resulted in BP elevation [48, 49, 80-82]. Several prospective studies suggested that higher circulating uric acid levels predict an increase in BP and development of hypertension in normotensive subjects [70, 83-87]. It was reported that higher SUA levels are associated with increased proximal tubular sodium reabsorption [88]. However, a study in older men did not find a correlation between SUA levels and incident hypertension [89].

\section{b. Uric Acid and Kidney Disease}

Chronic kidney disease (CKD) is associated with increased vascular risk [90-92]. In the general population, SUA levels correlate with serum creatinine levels [3, 6, 13, 89] and are inversely associated with estimated glomerular filtration rate (eGFR) [13, 84, 89]. SUA levels correlated 
with urinary albumin excretion in patients with T2DM [93, 94] and in some studies in hypertensive patients [95]. However, SUA levels did not correlate with microalbuminuria in other studies in hypertensive patients [72] or in normotensive subjects [96].

It was proposed that uric acid might be involved in the development of CKD [97]. In animal studies, experimental hyperuricemia is associated with increasing proteinuria, worsening renal function, glomerulosclerosis, renal interstitial fibrosis and preglomerular vasculopathy [48, 49, 80, 81]. Increased renal renin expression appears to be implicated in these adverse effects of uric acid on renal function [48, 81]. In humans, hyperuricemia also appears to be associated with an activated intrarenal renin-angiotensin system [98]. Some studies in the general population showed a relationship between elevated SUA levels and increased incidence of CKD [99, 100]. In the Cardiovascular Health Study, SUA levels did not predict incident CKD but were independently associated with the progression of pre-existing CKD [101].

\section{c. Uric Acid and Insulin Resistance}

In the general population, circulating uric acid levels are inversely associated with insulin sensitivity [84]. SUA levels also correlate with other markers of insulin resistance, including elevated triglyceride levels [11, 70, 89] and lower high density lipoprotein cholesterol levels [13, 69]. In addition, SUA levels correlate with markers of obesity, including body mass index (BMI) [3, 11, 13, 69, 70, 84, 89] and waist circumference $[69,70]$. Insulin resistance is inversely associated with urinary uric acid clearance [102] and experimental insulin infusion decreased urinary excretion of uric acid [103-105]. Patients with MetS may have higher SUA levels $[54,106,107]$ and this is also observed in children and adolescents with MetS [108]. Interestingly, diabetic patients may have lower SUA levels [6, 12, 13].

Even though elevated SUA levels appear to reflect insulin resistance, prospective studies in the general population suggested that elevated SUA levels might also be associated with increased risk for incident hyperinsulinemia [109] and T2DM [5, 69, 110]. In addition, higher SUA levels predicted an increase in BMI in non-obese subjects [111].

\section{d. Association of SUA Levels with other Vascular Risk Factors}

SUA levels are higher in men than in women [3, 4, 73]. In the general population, SUA levels do not change substantially with age in men, whereas in women they increase after the menopause [4]. SUA levels might be more predictive of vascular risk in women than in men [1].

In the general population, SUA levels also directly correlate with other vascular risk factors, including total cholesterol levels [3, 11, 13, 70, 89], increased alcohol consumption $[3,6,13,70]$ and less physical activity [6].

The relationship between SUA levels and smoking is controversial, with some studies reporting higher SUA levels in smokers $[11,13]$ and others lower $[6,12,70]$.

SUA levels might differ among ethnic groups. Some reports suggested that black subjects have lower SUA levels than Caucasians [112] but larger studies reported the oppo- site [113]. Hispanics appear to have similar SUA levels with white subjects and lower than blacks [113].

\section{INTERVENTIONAL STUDIES}

Allopurinol, an inhibitor of uric acid production, improved EDV in high-risk patients with hyperuricemia [57], in hypertensive diabetic patients [114], in smokers [115] and in patients with heart failure [116-118]. A recent study also reported a reduction in $\mathrm{BP}$ with allopurinol in hypertensive adolescents with SUA levels $\geq 6 \mathrm{mg} / \mathrm{dl}$ [119]. A reduction in plasma renin activity and systemic vascular resistance was also observed [119]. In patients with hyperuricemia, allopurinol increased eGFR and reduced hsCRP levels and BP [120]. In patients with CKD, treatment with allopurinol appeared to delay the deterioration of kidney function [121, 122]. In patients undergoing coronary artery bypass graft surgery, allopurinol appears to reduce morbidity and mortality [123]. Oxypurinol, the active metabolite of allopurinol, might also improve outcome in patients with heart failure and elevated SUA levels [124]. However, allopurinol and oxypurinol not only reduce SUA levels but also inhibit the production of free radicals from $\mathrm{XO}$, an important oxidative enzyme [1]. Therefore, the relative contribution of the reduction in SUA levels to the beneficial effects of allopurinol and oxypurinol is unclear [1]. In one study, the improvement in EDV with allopurinol correlated with the decrease in SUA levels [118]. However, others reported that the antioxidant action of allopurinol and not the fall in SUA levels was the main driver of the improvement in endothelial function [116]. In another study, lowering SUA levels with urate oxidase in diabetic patients did not improve endothelial dysfunction or arterial elasticity and did not reduce BP [125].

Several cardiovascular drugs can affect SUA levels [126]. Treatment with diuretics raises SUA levels, particularly when used at higher doses [3, 13, 74]. In the Systolic Hypertension in the Elderly Program (SHEP), hypertensive patients who showed an increase in SUA levels $<0.06$ $\mathrm{mmol} / \mathrm{l}$ during chlorthalidone treatment had lower risk for CHD events than patients with an increase $\geq 0.06 \mathrm{mmol} / \mathrm{l}$ [74]. This difference occurred despite the lower BP in the former patients [74]. However, there was no difference in stroke and total vascular events among patients with an increase in SUA levels < or $\geq 0.06 \mathrm{mmol} / 1$ [74]. In the LIFE study, losartan attenuated the increase in SUA levels compared with atenolol and this was associated with a reduction in vascular events [76]. Atorvastatin also decreases SUA levels $[106,127]$. In patients with CHD and MetS, a statininduced fall in serum uric acid levels was associated with reduced risk for vascular events [106]. However, when the change in renal function was considered, the change in SUA levels did not predict vascular risk [106].

\section{CONCLUSIONS}

It is unclear whether uric acid is a causal risk factor for vascular disease. Some evidence suggests that uric acid might be implicated in the development of hypertension, renal disease and insulin resistance. The complex interactions between SUA levels and established or emerging risk factors as well as treatments may explain the controversies in the literature. 
Until more conclusive data are available, patients with elevated SUA levels should be evaluated for the presence of more established risk factors (including T2DM, MetS and CKD) and treatment should be targeted against these factors.

\section{ABBREVIATIONS}

$$
\begin{array}{ll}
\text { ARIC } & \text { Atherosclerosis Risk in Communities } \\
\mathrm{BMI} & =\text { body mass index } \\
\mathrm{BP} & =\text { blood pressure } \\
\mathrm{CHD} & =\text { coronary heart disease } \\
\mathrm{CKD} & =\text { Chronic kidney disease } \\
\mathrm{CRP} & =\text { C-reactive protein } \\
\mathrm{EDV} & =\text { endothelium dependent vasodilation } \\
\text { eGFR } & =\text { estimated glomerular filtration rate } \\
\mathrm{HF} & =\text { heart failure } \\
\text { hsCRP } & =\text { high sensitivity CRP } \\
\mathrm{IL}-6 & =\text { interleukin-6 } \\
\mathrm{LIFE} & =\text { Losartan Intervention For Endpoint reduction } \\
\mathrm{MCP}-1 & =\text { in hypertension } \\
\mathrm{MetS} & =\text { metabolic syndrome } \\
\mathrm{MRFIT} & =\text { Multiple Risk Factor Intervention Trial } \\
\mathrm{NO} & =\text { nitric oxide } \\
\mathrm{PAD} & =\text { peripheral arterial disease } \\
\mathrm{SHEP} & =\text { Systolic Hypertension in the Elderly Program } \\
\mathrm{SUA} & =\text { serum uric acid }
\end{array}
$$$$
\text { Syst-Eur }=\text { Systolic Hypertension in Europe }
$$$$
\mathrm{T} 2 \mathrm{DM}=\text { type } 2 \text { diabetes mellitus }
$$$$
\mathrm{TNF} \alpha=\text { tumor necrosis factor- } \alpha
$$$$
\text { VSMC }=\text { vascular smooth muscle cells }
$$$$
\mathrm{XO}=\text { xanthine oxidase }
$$

\section{DECLARATION OF INTEREST}

This review was written independently; no company or institution supported it financially. Some of the authors have attended conferences, given lectures and participated in advisory boards or trials sponsored by various pharmaceutical companies.

Konstantinos Tziomalos is supported by a grant from the Hellenic Atherosclerosis Society.

\section{REFERENCES}

[1] Feig, D.I.; Kang, D.H.; Johnson, R.J. Uric acid and cardiovascular risk. N. Engl. J. Med., 2008, 359(17), 1811-1821.

[2] Bos, M.J.; Koudstaal, P.J.; Hofman, A.; Witteman, J.C.; Breteler, M.M. Uric acid is a risk factor for myocardial infarction and stroke: the Rotterdam study. Stroke, 2006, 37(6), 1503-1507.

[3] Fang, J.; Alderman, M.H. Serum uric acid and cardiovascular mortality the NHANES I epidemiologic follow-up study, 1971-1992. National Health and Nutrition Examination Survey. JAMA, 2000, 283(18), 2404-2410.
[4] Culleton, B.F.; Larson, M.G.; Kannel, W.B.; Levy, D. Serum uric acid and risk for cardiovascular disease and death: the Framingham Heart Study. Ann. Intern. Med., 1999, 131(1), 7-13.

[5] Krishnan, E.; Svendsen, K.; Neaton, J.D.; Grandits, G.; Kuller, L.H. Long-term cardiovascular mortality among middle-aged men with gout. Arch. Intern. Med., 2008, 168(10), 1104-1110.

[6] Wannamethee, S.G.; Shaper, A.G.; Whincup, P.H. Serum urate and the risk of major coronary heart disease events. Heart, 1997, 78(2), 147-153.

[7] Petersen, T.S.; Madsen, T.V.; Jespersen, J.B.; Larsen, A.; Schmidt, E.B.; Christensen, J.H. Uric acid in patients with angiographically documented coronary heart disease. Acta Cardiol., 2006, 61(5), 525-529.

[8] Santos, R.D.; Nasir, K.; Orakzai, R.; Meneghelo, R.S.; Carvalho, J.A.; Blumenthal, R.S. Relation of uric acid levels to presence of coronary artery calcium detected by electron beam tomography in men free of symptomatic myocardial ischemia with versus without the metabolic syndrome. Am. J. Cardiol., 2007, 99(1), 42-45.

[9] Coutinho, T.A.; Turner, S.T.; Peyser, P.A.; Bielak, L.F.; Sheedy, P.F.; Kullo, I.J. Associations of serum uric acid with markers of inflammation, metabolic syndrome, and subclinical coronary atherosclerosis. Am. J. Hypertens., 2007, 20(1), 83-89.

[10] Wheeler, J.G.; Juzwishin, K.D.; Eiriksdottir, G.; Gudnason, V.; Danesh, J. Serum uric acid and coronary heart disease in 9,458 incident cases and 155,084 controls: prospective study and metaanalysis. PLoS. Med., 2005, 2(3), e76.

[11] Strasak, A.; Ruttmann, E.; Brant, L.; Kelleher, C.; Klenk, J.; Concin, H.; Diem, G.; Pfeiffer, K.; Ulmer, H. Serum uric acid and risk of cardiovascular mortality: a prospective long-term study of 83,683 Austrian men. Clin. Chem., 2008, 54(2), 273-284.

[12] Gerber, Y.; Tanne, D.; Medalie, J.H.; Goldbourt, U. Serum uric acid and long-term mortality from stroke, coronary heart disease and all causes. Eur. J. Cardiovasc. Prev. Rehabil., 2006, 13(2), 193-198.

[13] Meisinger, C.; Koenig, W.; Baumert, J.; Doring, A. Uric acid levels are associated with all-cause and cardiovascular disease mortality independent of systemic inflammation in men from the general population: the MONICA/KORA cohort study. Arterioscler. Thromb. Vasc. Biol., 2008, 28(6), 1186-1192.

[14] Strasak, A.M.; Kelleher, C.C.; Brant, L.J.; Rapp, K.; Ruttmann, E.; Concin, H.; Diem, G.; Pfeiffer, K.P.; Ulmer, H. Serum uric acid is an independent predictor for all major forms of cardiovascular death in 28,613 elderly women: a prospective 21-year follow-up study. Int. J. Cardiol., 2008, 125(2), 232-239.

[15] Iribarren, C.; Folsom, A.R.; Eckfeldt, J.H.; McGovern, P.G.; Nieto, F.J. Correlates of uric acid and its association with asymptomatic carotid atherosclerosis: the ARIC Study. Atherosclerosis Risk in Communities. Ann. Epidemiol., 1996, 6(4), 331-340.

[16] Neogi, T.; Ellison, R.C.; Hunt, S.; Terkeltaub, R.; Felson, D.T.; Zhang, Y. Serum uric acid is associated with carotid plaques: the National Heart, Lung, and Blood Institute Family Heart Study. $J$. Rheumatol., 2009, 36(2), 378-384.

[17] Milionis, H.J.; Kalantzi, K.J.; Goudevenos, J.A.; Seferiadis, K.; Mikhailidis, D.P.; Elisaf, M.S. Serum uric acid levels and risk for acute ischaemic non-embolic stroke in elderly subjects. J. Intern. Med., 2005, 258(5), 435-441.

[18] Mazza, A.; Pessina, A.C.; Pavei, A.; Scarpa, R.; Tikhonoff, V.; Casiglia, E. Predictors of stroke mortality in elderly people from the general population. The Cardiovascular Study in the Elderly. Eur. J. Epidemiol., 2001, 17(12), 1097-1104.

[19] Lehto, S.; Niskanen, L.; Ronnemaa, T.; Laakso, M. Serum uric acid is a strong predictor of stroke in patients with non-insulindependent diabetes mellitus. Stroke, 1998, 29(3), 635-639.

[20] Hozawa, A.; Folsom, A.R.; Ibrahim, H.; Javier, N.F.; Rosamond, W.D.; Shahar, E. Serum uric acid and risk of ischemic stroke: the ARIC Study. Atherosclerosis, 2006, 187(2), 401-407.

[21] Langlois, M.; De Bacquer, D.; Duprez, D.; De Buyzere, M.; Delanghe, J.; Blaton, V. Serum uric acid in hypertensive patients with and without peripheral arterial disease. Atherosclerosis, 2003, 168(1), 163-168.

[22] Baker, J.F.; Schumacher, H.R.; Krishnan, E. Serum uric acid level and risk for peripheral arterial disease: analysis of data from the multiple risk factor intervention trial. Angiology, 2007, 58(4), 450457.

[23] Niskanen, L.K.; Laaksonen, D.E.; Nyyssonen, K.; Alfthan, G.; Lakka, H.M.; Lakka, T.A.; Salonen, J.T. Uric acid level as a risk 
factor for cardiovascular and all-cause mortality in middle-aged men: a prospective cohort study. Arch. Intern. Med., 2004, 164(14), 1546-1551.

[24] Bickel, C.; Rupprecht, H.J.; Blankenberg, S.; Rippin, G.; Hafner, G.; Daunhauer, A.; Hofmann, K.P.; Meyer, J. Serum uric acid as an independent predictor of mortality in patients with angiographically proven coronary artery disease. Am. J. Cardiol., 2002, 89(1), 1217.

[25] Ruilope, L.M.; Kirwan, B.A.; de Brouwer, S.; Danchin, N.; Fox, K.A.; Wagener, G.; Segura, J.; Poole-Wilson, P.A.; Lubsen, J. Uric acid and other renal function parameters in patients with stable angina pectoris participating in the ACTION trial: impact of nifedipine GITS (gastro-intestinal therapeutic system) and relation to outcome. J. Hypertens., 2007, 25(8), 1711-1718.

[26] Cherubini, A.; Polidori, M.C.; Bregnocchi, M.; Pezzuto, S.; Cecchetti, R.; Ingegni, T.; di Iorio, A.; Senin, U.; Mecocci, P. Antioxidant profile and early outcome in stroke patients. Stroke, 2000, 31(10), 2295-2300.

[27] Weir, C.J.; Muir, S.W.; Walters, M.R.; Lees, K.R. Serum urate as an independent predictor of poor outcome and future vascular events after acute stroke. Stroke, 2003, 34(8), 1951-1956.

[28] Karagiannis, A.; Mikhailidis, D.P.; Tziomalos, K.; Sileli, M.; Savvatianos, S.; Kakafika, A.; Gossios, T.; Krikis, N.; Moschou, I.; Xochellis, M.; Athyros, V.G. Serum uric acid as an independent predictor of early death after acute stroke. Circ. J., 2007, 71(7), 1120-1127.

[29] Wong, K.Y.; MacWalter, R.S.; Fraser, H.W.; Crombie, I.; Ogston, S.A.; Struthers, A.D. Urate predicts subsequent cardiac death in stroke survivors. Eur. Heart J., 2002, 23(10), 788-793.

[30] Newman, E.J.; Rahman, F.S.; Lees, K.R.; Weir, C.J.; Walters, M.R. Elevated serum urate concentration independently predicts poor outcome following stroke in patients with diabetes. Diabetes $M e$ tab. Res. Rev., 2006, 22(1), 79-82.

[31] Chamorro, A.; Obach, V.; Cervera, A.; Revilla, M.; Deulofeu, R.; Aponte, J.H. Prognostic significance of uric acid serum concentration in patients with acute ischemic stroke. Stroke, 2002, 33(4), 1048-1052.

[32] Dimitroula, H.V.; Hatzitolios, A.I.; Karvounis, H.I. The role of uric acid in stroke: the issue remains unresolved. Neurologist, 2008, 14(4), 238-242.

[33] Leyva, F.; Anker, S.D.; Godsland, I.F.; Teixeira, M.; Hellewell, P.G.; Kox, W.J.; Poole-Wilson, P.A.; Coats, A.J. Uric acid in chronic heart failure: a marker of chronic inflammation. Eur. Heart J., 1998, 19(12), 1814-1822.

[34] Leyva, F.; Anker, S.; Swan, J.W.; Godsland, I.F.; Wingrove, C.S.; Chua, T.P.; Stevenson, J.C.; Coats, A.J. Serum uric acid as an index of impaired oxidative metabolism in chronic heart failure. Eur. Heart J., 1997, 18(5), 858-865.

[35] Kittleson, M.M.; St John, M.E.; Bead, V.; Champion, H.C.; Kasper, E.K.; Russell, S.D.; Wittstein, I.S.; Hare, J.M. Increased levels of uric acid predict haemodynamic compromise in patients with heart failure independently of B-type natriuretic peptide levels. Heart, 2007, 93(3), 365-367.

[36] Chrysohoou, C.; Pitsavos, C.; Barbetseas, J.; Brili, S.; Kotroyiannis, I.; Papademetriou, L.; Metallinos, G.; Skoumas, J.; Tentolouris, C.; Stefanadis, C. Serum uric acid levels correlate with left atrial function and systolic right ventricular function in patients with newly diagnosed heart failure: the hellenic heart failure study. Congest. Heart Fail., 2008, 14(5), 229-233.

[37] Hare, J.M.; Johnson, R.J. Uric acid predicts clinical outcomes in heart failure: insights regarding the role of xanthine oxidase and uric acid in disease pathophysiology. Circulation, 2003, 107(15), 1951-1953.

[38] Tziomalos, K.; Hare, J.M. Role of xanthine oxidoreductase in cardiac nitroso-redox imbalance. Front Biosci., 2009, 14, 237-262.

[39] Anker, S.D.; Doehner, W.; Rauchhaus, M.; Sharma, R.; Francis, D.; Knosalla, C.; Davos, C.H.; Cicoira, M.; Shamim, W.; Kemp, M.; Segal, R.; Osterziel, K.J.; Leyva, F.; Hetzer, R.; Ponikowski, P.; Coats, A.J. Uric acid and survival in chronic heart failure: validation and application in metabolic, functional, and hemodynamic staging. Circulation, 2003, 107(15), 1991-1997.

[40] Sakai, H.; Tsutamoto, T.; Tsutsui, T.; Tanaka, T.; Ishikawa, C.; Horie, M. Serum level of uric acid, partly secreted from the failing heart, is a prognostic marker in patients with congestive heart failure. Circ. J., 2006, 70(8), 1006-1011.
[41] Jankowska, E.A.; Ponikowska, B.; Majda, J.; Zymlinski, R.; Trzaska, M.; Reczuch, K.; Borodulin-Nadzieja, L.; Banasiak, W.; Ponikowski, P. Hyperuricaemia predicts poor outcome in patients with mild to moderate chronic heart failure. Int. J. Cardiol., 2007, 115(2), 151-155.

[42] Kanellis, J.; Watanabe, S.; Li, J.H.; Kang, D.H.; Li, P.; Nakagawa, T.; Wamsley, A.; Sheikh-Hamad, D.; Lan, H.Y.; Feng, L.; Johnson, R.J. Uric acid stimulates monocyte chemoattractant protein-1 production in vascular smooth muscle cells via mitogen-activated protein kinase and cyclooxygenase-2. Hypertension, 2003, 41(6), 1287-1293.

[43] Kang, D.H.; Park, S.K.; Lee, I.K.; Johnson, R.J. Uric acid-induced C-reactive protein expression: implication on cell proliferation and nitric oxide production of human vascular cells. J. Am. Soc. Nephrol., 2005, 16(12), 3553-3562.

[44] Netea, M.G.; Kullberg, B.J.; Blok, W.L.; Netea, R.T.; van der Meer, J.W. The role of hyperuricemia in the increased cytokine production after lipopolysaccharide challenge in neutropenic mice. Blood, 1997, 89(2), 577-582.

[45] Frohlich, M.; Imhof, A.; Berg, G.; Hutchinson, W.L.; Pepys, M.B.; Boeing, H.; Muche, R.; Brenner, H.; Koenig, W. Association between C-reactive protein and features of the metabolic syndrome: a population-based study. Diabetes Care, 2000, 23(12), 1835-1839.

[46] Ruggiero, C.; Cherubini, A.; Ble, A.; Bos, A.J.; Maggio, M.; Dixit, V.D.; Lauretani, F.; Bandinelli, S.; Senin, U.; Ferrucci, L. Uric acid and inflammatory markers. Eur. Heart J., 2006, 27(10), 1174-1181.

[47] Ruggiero, C.; Cherubini, A.; Miller, E., III; Maggio, M.; Najjar, S.S.; Lauretani, F.; Bandinelli, S.; Senin, U.; Ferrucci, L. Usefulness of uric acid to predict changes in C-reactive protein and interleukin-6 in 3-year period in Italians aged 21 to 98 years. Am. J. Cardiol., 2007, 100(1), 115-121.

[48] Kang, D.H.; Nakagawa, T.; Feng, L.; Watanabe, S.; Han, L.; Mazzali, M.; Truong, L.; Harris, R.; Johnson, R.J. A role for uric acid in the progression of renal disease. J. Am. Soc. Nephrol., 2002, 13(12), 2888-2897.

[49] Mazzali, M.; Kanellis, J.; Han, L.; Feng, L.; Xia, Y.Y.; Chen, Q.; Kang, D.H.; Gordon, K.L.; Watanabe, S.; Nakagawa, T.; Lan, H.Y.; Johnson, R.J. Hyperuricemia induces a primary renal arteriolopathy in rats by a blood pressure-independent mechanism. Am. J. Physiol. Renal Physiol., 2002, 282(6), F991-F997.

[50] Rao, G.N.; Corson, M.A.; Berk, B.C. Uric acid stimulates vascular smooth muscle cell proliferation by increasing platelet-derived growth factor A-chain expression. J. Biol. Chem., 1991, 266(13), 8604-8608.

[51] Suarna, C.; Dean, R.T.; May, J.; Stocker, R. Human atherosclerotic plaque contains both oxidized lipids and relatively large amounts of alpha-tocopherol and ascorbate. Arterioscler. Thromb. Vasc. Biol., 1995, 15(10), 1616-1624.

[52] Khosla, U.M.; Zharikov, S.; Finch, J.L.; Nakagawa, T.; Roncal, C.; Mu, W.; Krotova, K.; Block, E.R.; Prabhakar, S.; Johnson, R.J. Hyperuricemia induces endothelial dysfunction. Kidney Int., 2005, 67(5), 1739-1742.

[53] Kanabrocki, E.L.; Third, J.L.; Ryan, M.D.; Nemchausky, B.A.; Shirazi, P.; Scheving, L.E.; McCormick, J.B.; Hermida, R.C. Bremner, W.F.; Hoppensteadt, D.A.; Fareed, J.; Olwin, J.H. Circadian relationship of serum uric acid and nitric oxide. JAMA, 2000, 283(17), 2240-2241.

[54] Zoccali, C.; Maio, R.; Mallamaci, F.; Sesti, G.; Perticone, F. Uric acid and endothelial dysfunction in essential hypertension. J. Am. Soc. Nephrol., 2006, 17(5), 1466-1471.

[55] Erdogan, D.; Gullu, H.; Caliskan, M.; Yildirim, E.; Bilgi, M.; Ulus, T.; Sezgin, N.; Muderrisoglu, H. Relationship of serum uric acid to measures of endothelial function and atherosclerosis in healthy adults. Int. J. Clin. Pract., 2005, 59(11), 1276-1282.

[56] Kato, M.; Hisatome, I.; Tomikura, Y.; Kotani, K.; Kinugawa, T.; Ogino, K.; Ishida, K.; Igawa, O.; Shigemasa, C.; Somers, V.K. Status of endothelial dependent vasodilation in patients with hyperuricemia. Am. J. Cardiol., 2005, 96(11), 1576-1578.

[57] Mercuro, G.; Vitale, C.; Cerquetani, E.; Zoncu, S.; Deidda, M.; Fini, M.; Rosano, G.M. Effect of hyperuricemia upon endothelial function in patients at increased cardiovascular risk. Am. J. Cardiol., 2004, 94(7), 932-935.

[58] Waring, W.S.; Adwani, S.H.; Breukels, O.; Webb, D.J.; Maxwell, S.R. Hyperuricaemia does not impair cardiovascular function in healthy adults. Heart, 2004, 90(2), 155-159. 
[59] Waring, W.S.; McKnight, J.A.; Webb, D.J.; Maxwell, S.R. Uric acid restores endothelial function in patients with type 1 diabetes and regular smokers. Diabetes, 2006, 55(11), 3127-3132.

[60] Khan, F.; George, J.; Wong, K.; McSwiggan, S.; Struthers, A.D.; Belch, J.J. The association between serum urate levels and arterial stiffness/endothelial function in stroke survivors. Atherosclerosis, 2008, 200(2), 374-379.

[61] Kullo, I.J.; Malik, A.R. Arterial ultrasonography and tonometry as adjuncts to cardiovascular risk stratification. J. Am. Coll. Cardiol., 2007, 49(13), 1413-1426.

[62] Maxwell, S.R.; Thomason, H.; Sandler, D.; Leguen, C.; Baxter, M.A.; Thorpe, G.H.; Jones, A.F.; Barnett, A.H. Antioxidant status in patients with uncomplicated insulin-dependent and non-insulindependent diabetes mellitus. Eur. J. Clin. Invest, 1997, 27(6), 484490 .

[63] Nyyssonen, K.; Porkkala-Sarataho, E.; Kaikkonen, J.; Salonen, J.T. Ascorbate and urate are the strongest determinants of plasma antioxidative capacity and serum lipid resistance to oxidation in Finnish men. Atherosclerosis, 1997, 130(1-2), 223-233.

[64] Waring, W.S.; Convery, A.; Mishra, V.; Shenkin, A.; Webb, D.J.; Maxwell, S.R. Uric acid reduces exercise-induced oxidative stress in healthy adults. Clin. Sci. (Lond), 2003, 105(4), 425-430.

[65] Waring, W.S.; Webb, D.J.; Maxwell, S.R. Systemic uric acid administration increases serum antioxidant capacity in healthy volunteers. J. Cardiovasc. Pharmacol., 2001, 38(3), 365-371.

[66] Abuja, P.M. Ascorbate prevents prooxidant effects of urate in oxidation of human low density lipoprotein. FEBS Lett., 1999, 446(23), 305-308.

[67] Bagnati, M.; Perugini, C.; Cau, C.; Bordone, R.; Albano, E.; Bellomo, G. When and why a water-soluble antioxidant becomes prooxidant during copper-induced low-density lipoprotein oxidation: a study using uric acid. Biochem. J., 1999, 340(Pt 1), 143-152.

[68] Patterson, R.A.; Horsley, E.T.; Leake, D.S. Prooxidant and antioxidant properties of human serum ultrafiltrates toward LDL: important role of uric acid. J. Lipid Res., 2003, 44(3), 512-521.

[69] Dehghan, A.; van Hoek, M.; Sijbrands, E.J.; Hofman, A.; Witteman, J.C. High serum uric acid as a novel risk factor for type 2 diabetes. Diabetes Care, 2008, 31(2), 361-362.

[70] Perlstein, T.S.; Gumieniak, O.; Williams, G.H.; Sparrow, D.; Vokonas, P.S.; Gaziano, M.; Weiss, S.T.; Litonjua, A.A. Uric acid and the development of hypertension: the normative aging study. $\mathrm{Hy}$ pertension, 2006, 48(6), 1031-1036.

[71] Viazzi, F.; Parodi, D.; Leoncini, G.; Parodi, A.; Falqui, V.; Ratto, E.; Vettoretti, S.; Bezante, G.P.; Del, S.M.; Deferrari, G.; Pontremoli, R. Serum uric acid and target organ damage in primary hypertension. Hypertension, 2005, 45(5), 991-996.

[72] Cuspidi, C.; Valerio, C.; Sala, C.; Meani, S.; Esposito, A.; Zanchetti, A.; Mancia, G. Lack of association between serum uric acid and organ damage in a never-treated essential hypertensive population at low prevalence of hyperuricemia. Am. J. Hypertens., 2007, 20(6), 678-685.

[73] Alderman, M.H.; Cohen, H.; Madhavan, S.; Kivlighn, S. Serum uric acid and cardiovascular events in successfully treated hypertensive patients. Hypertension, 1999, 34(1), 144-150.

[74] Franse, L.V.; Pahor, M.; Di Bari, M.; Shorr, R.I.; Wan, J.Y.; Somes, G.W.; Applegate, W.B. Serum uric acid, diuretic treatment and risk of cardiovascular events in the Systolic Hypertension in the Elderly Program (SHEP). J. Hypertens., 2000, 18(8), 11491154.

[75] Gueyffier, F.; Boissel, J.P.; Pocock, S.; Boutitie, F.; Coope, J.; Cutler, J.; Ekbom, T.; Fagard, R.; Friedman, L.; Kerlikowske, K.; Perry, M.; Prineas, R.; Schron, E. Identification of risk factors in hypertensive patients: contribution of randomized controlled trials through an individual patient database. Circulation, 1999, 100(18), e88-e94.

[76] Hoieggen, A.; Alderman, M.H.; Kjeldsen, S.E.; Julius, S.; Devereux, R.B.; De, F.U.; Fyhrquist, F.; Ibsen, H.; Kristianson, K.; Lederballe-Pedersen, O.; Lindholm, L.H.; Nieminen, M.S.; Omvik, P.; Oparil, S.; Wedel, H.; Chen, C.; Dahlof, B. The impact of serum uric acid on cardiovascular outcomes in the LIFE study. Kidney Int., 2004, 65(3), 1041-1049.

[77] De Leeuw, P.W.; Thijs, L.; Birkenhager, W.H.; Voyaki, S.M.; Efstratopoulos, A.D.; Fagard, R.H.; Leonetti, G.; Nachev, C.; Petrie, J.C.; Rodicio, J.L.; Rosenfeld, J.J.; Sarti, C.; Staessen, J.A. Prognostic significance of renal function in elderly patients with isolated systolic hypertension: results from the Syst-Eur trial. $J$. Am. Soc. Nephrol., 2002, 13(9), 2213-2222.

[78] Verdecchia, P.; Schillaci, G.; Reboldi, G.; Santeusanio, F.; Porcellati, C.; Brunetti, P. Relation between serum uric acid and risk of cardiovascular disease in essential hypertension. The PIUMA study. Hypertension, 2000, 36(6), 1072-1078.

[79] Feig, D.I.; Mazzali, M.; Kang, D.H.; Nakagawa, T.; Price, K.; Kannelis, J.; Johnson, R.J. Serum uric acid: a risk factor and a target for treatment? J. Am. Soc. Nephrol., 2006, 17(4 Suppl 2), S69S73.

[80] Nakagawa, T.; Mazzali, M.; Kang, D.H.; Kanellis, J.; Watanabe, S.; Sanchez-Lozada, L.G.; Rodriguez-Iturbe, B.; Herrera-Acosta, J.; Johnson, R.J. Hyperuricemia causes glomerular hypertrophy in the rat. Am. J. Nephrol., 2003, 23(1), 2-7.

[81] Mazzali, M.; Hughes, J.; Kim, Y.G.; Jefferson, J.A.; Kang, D.H.; Gordon, K.L.; Lan, H.Y.; Kivlighn, S.; Johnson, R.J. Elevated uric acid increases blood pressure in the rat by a novel crystalindependent mechanism. Hypertension, 2001, 38(5), 1101-1106.

[82] Sanchez-Lozada, L.G.; Tapia, E.; vila-Casado, C.; Soto, V.; Franco, M.; Santamaria, J.; Nakagawa, T.; Rodriguez-Iturbe, B.; Johnson, R.J.; Herrera-Acosta, J. Mild hyperuricemia induces glomerular hypertension in normal rats. Am. J. Physiol. Renal Physiol., 2002, 283(5), F1105-F1110.

[83] Alper, A.B., Jr.; Chen, W.; Yau, L.; Srinivasan, S.R.; Berenson, G.S.; Hamm, L.L. Childhood uric acid predicts adult blood pressure: the Bogalusa Heart Study. Hypertension, 2005, 45(1), 34-38.

[84] Forman, J.P.; Choi, H.; Curhan, G.C. Uric acid and insulin sensitivity and risk of incident hypertension. Arch. Intern. Med., 2009, 169(2), 155-162.

[85] Krishnan, E.; Kwoh, C.K.; Schumacher, H.R.; Kuller, L. Hyperuricemia and incidence of hypertension among men without metabolic syndrome. Hypertension, 2007, 49(2), 298-303.

[86] Shankar, A.; Klein, R.; Klein, B.E.; Nieto, F.J. The association between serum uric acid level and long-term incidence of hypertension: Population-based cohort study. J. Hum. Hypertens., 2006, 20(12), 937-945.

[87] Sundstrom, J.; Sullivan, L.; D'Agostino, R.B.; Levy, D.; Kannel, W.B.; Vasan, R.S. Relations of serum uric acid to longitudinal blood pressure tracking and hypertension incidence. Hypertension, 2005, 45(1), 28-33.

[88] Cappuccio, F.P.; Strazzullo, P.; Farinaro, E.; Trevisan, M. Uric acid metabolism and tubular sodium handling. Results from a population-based study. JAMA, 1993, 270(3), 354-359.

[89] Forman, J.P.; Choi, H.; Curhan, G.C. Plasma uric acid level and risk for incident hypertension among men. J. Am. Soc. Nephrol., 2007, 18(1), 287-292.

[90] Astor, B.C.; Hallan, S.I.; Miller, E.R., III; Yeung, E.; Coresh, J. Glomerular filtration rate, albuminuria, and risk of cardiovascular and all-cause mortality in the US population. Am. J. Epidemiol., 2008, 167(10), 1226-1234.

[91] Van Biesen, W.; De Bacquer, D.; Verbeke, F.; Delanghe, J.; Lameire, N.; Vanholder, R. The glomerular filtration rate in an apparently healthy population and its relation with cardiovascular mortality during 10 years. Eur. Heart J., 2007, 28(4), 478-483.

[92] Go, A.S.; Chertow, G.M.; Fan, D.; McCulloch, C.E.; Hsu, C.Y. Chronic kidney disease and the risks of death, cardiovascular events, and hospitalization. N. Engl. J. Med., 2004, 351(13), 12961305.

[93] Bo, S.; Cavallo-Perin, P.; Gentile, L.; Repetti, E.; Pagano, G. Hypouricemia and hyperuricemia in type 2 diabetes: two different phenotypes. Eur. J. Clin. Invest., 2001, 31(4), 318-321.

[94] Bruno, G.; Cavallo-Perin, P.; Bargero, G.; Borra, M.; Calvi, V.; D'Errico, N.; Deambrogio, P.; Pagano, G. Prevalence and risk factors for micro- and macroalbuminuria in an Italian populationbased cohort of NIDDM subjects. Diabetes Care, 1996, 19(1), 4347.

[95] Mattei, P.; Arzilli, F.; Giovannetti, R.; Penno, G.; Arrighi, P.; Taddei, S.; Salvetti, A. Microalbuminuria and renal haemodynamics in essential hypertension. Eur. J. Clin. Invest., 1997, 27(9), 755-760.

[96] Lee, J.E.; Kim, Y.G.; Choi, Y.H.; Huh, W.; Kim, D.J.; Oh, H.Y. Serum uric acid is associated with microalbuminuria in prehypertension. Hypertension, 2006, 47(5), 962-967.

[97] Johnson, R.J.; Segal, M.S.; Srinivas, T.; Ejaz, A.; Mu, W.; Roncal, C.; Sanchez-Lozada, L.G.; Gersch, M.; Rodriguez-Iturbe, B.; Kang, D.H.; Acosta, J.H. Essential hypertension, progressive renal dis- 
ease, and uric acid: a pathogenetic link? J. Am. Soc. Nephrol., 2005, 16(7), 1909-1919.

[98] Perlstein, T.S.; Gumieniak, O.; Hopkins, P.N.; Murphey, L.J.; Brown, N.J.; Williams, G.H.; Hollenberg, N.K.; Fisher, N.D. Uric acid and the state of the intrarenal renin-angiotensin system in humans. Kidney Int., 2004, 66(4), 1465-1470.

[99] Obermayr, R.P.; Temml, C.; Gutjahr, G.; Knechtelsdorfer, M.; Oberbauer, R.; Klauser-Braun, R. Elevated uric acid increases the risk for kidney disease. J. Am. Soc. Nephrol., 2008, 19(12), 24072413.

[100] Weiner, D.E.; Tighiouart, H.; Elsayed, E.F.; Griffith, J.L.; Salem, D.N.; Levey, A.S. Uric acid and incident kidney disease in the community. J. Am. Soc. Nephrol., 2008, 19(6), 1204-1211.

[101] Chonchol, M.; Shlipak, M.G.; Katz, R.; Sarnak, M.J.; Newman, A.B.; Siscovick, D.S.; Kestenbaum, B.; Carney, J.K.; Fried, L.F. Relationship of uric acid with progression of kidney disease. Am. J. Kidney Dis., 2007, 50(2), 239-247.

[102] Facchini, F.; Chen, Y.D.; Hollenbeck, C.B.; Reaven, G.M. Relationship between resistance to insulin-mediated glucose uptake, urinary uric acid clearance, and plasma uric acid concentration. JAMA, 1991, 266(21), 3008-3011.

[103] Ter Maaten, J.C.; Voorburg, A.; Heine, R.J.; Ter Wee, P.M.; Donker, A.J.; Gans, R.O. Renal handling of urate and sodium during acute physiological hyperinsulinaemia in healthy subjects. Clin. Sci. (Lond), 1997, 92(1), 51-58.

[104] Quinones, G.A.; Natali, A.; Baldi, S.; Frascerra, S.; Sanna, G.; Ciociaro, D.; Ferrannini, E. Effect of insulin on uric acid excretion in humans. Am. J. Physiol., 1995, 268(1 Pt 1), E1-E5.

[105] Muscelli, E.; Natali, A.; Bianchi, S.; Bigazzi, R.; Galvan, A.Q.; Sironi, A.M.; Frascerra, S.; Ciociaro, D.; Ferrannini, E. Effect of insulin on renal sodium and uric acid handling in essential hypertension. Am. J. Hypertens., 1996, 9(8), 746-752.

[106] Athyros, V.G.; Mikhailidis, D.P.; Liberopoulos, E.N.; Kakafika, A.I.; Karagiannis, A.; Papageorgiou, A.A.; Tziomalos, K.; Ganotakis, E.S.; Elisaf, M. Effect of statin treatment on renal function and serum uric acid levels and their relation to vascular events in patients with coronary heart disease and metabolic syndrome: a subgroup analysis of the GREek Atorvastatin and Coronary heart disease Evaluation (GREACE) Study. Nephrol. Dial. Transplant., 2007, 22(1), 118-127.

[107] Tsouli, S.G.; Liberopoulos, E.N.; Mikhailidis, D.P.; Athyros, V.G.; Elisaf, M.S. Elevated serum uric acid levels in metabolic syndrome: an active component or an innocent bystander? Metabolism, 2006, 55(10), 1293-1301.

[108] Ford, E.S.; Li, C.; Cook, S.; Choi, H.K. Serum concentrations of uric acid and the metabolic syndrome among US children and adolescents. Circulation, 2007, 115(19), 2526-2532.

[109] Carnethon, M.R.; Fortmann, S.P.; Palaniappan, L.; Duncan, B.B.; Schmidt, M.I.; Chambless, L.E. Risk factors for progression to incident hyperinsulinemia: the Atherosclerosis Risk in Communities Study, 1987-1998. Am. J. Epidemiol., 2003, 158(11), 1058-1067.

[110] Perry, I.J.; Wannamethee, S.G.; Walker, M.K.; Thomson, A.G.; Whincup, P.H.; Shaper, A.G. Prospective study of risk factors for development of non-insulin dependent diabetes in middle aged British men. BMJ, 1995, 310(6979), 560-564.

[111] Masuo, K.; Kawaguchi, H.; Mikami, H.; Ogihara, T.; Tuck, M.L. Serum uric acid and plasma norepinephrine concentrations predict subsequent weight gain and blood pressure elevation. Hypertension, 2003, 42(4), 474-480.

[112] Palmer, I.M.; Schutte, A.E.; Huisman, H.W.; Van Rooyen, J.M.; Schutte, R.; Malan, L.; Malan, N.T. A comparison of uric acid lev- els in Black African vs Caucasian women from South Africa: the POWIRS study. Ethn. Dis., 2007, 17(4), 676-681.

[113] Foley, R.N.; Wang, C.; Ishani, A.; Collins, A.J. NHANES III: influence of race on GFR thresholds and detection of metabolic abnormalities. J. Am. Soc. Nephrol., 2007, 18(9), 2575-2582.

[114] Butler, R.; Morris, A.D.; Belch, J.J.; Hill, A.; Struthers, A.D. Allopurinol normalizes endothelial dysfunction in type 2 diabetics with mild hypertension. Hypertension, 2000, 35(3), 746-751.

[115] Guthikonda, S.; Sinkey, C.; Barenz, T.; Haynes, W.G. Xanthine oxidase inhibition reverses endothelial dysfunction in heavy smokers. Circulation, 2003, 107(3), 416-421.

[116] George, J.; Carr, E.; Davies, J.; Belch, J.J.; Struthers, A. High-dose allopurinol improves endothelial function by profoundly reducing vascular oxidative stress and not by lowering uric acid. Circulation, 2006, 114(23), 2508-2516.

[117] Farquharson, C.A.; Butler, R.; Hill, A.; Belch, J.J.; Struthers, A.D. Allopurinol improves endothelial dysfunction in chronic heart failure. Circulation, 2002, 106(2), 221-226.

[118] Doehner, W.; Schoene, N.; Rauchhaus, M.; Leyva-Leon, F.; Pavitt, D.V.; Reaveley, D.A.; Schuler, G.; Coats, A.J.; Anker, S.D.; Hambrecht, R. Effects of xanthine oxidase inhibition with allopurinol on endothelial function and peripheral blood flow in hyperuricemic patients with chronic heart failure: results from 2 placebocontrolled studies. Circulation, 2002, 105(22), 2619-2624.

[119] Feig, D.I.; Soletsky, B.; Johnson, R.J. Effect of allopurinol on blood pressure of adolescents with newly diagnosed essential hypertension: a randomized trial. JAMA, 2008, 300(8), 924-932.

[120] Kanbay, M.; Ozkara, A.; Selcoki, Y.; Isik, B.; Turgut, F.; Bavbek, N.; Uz, E.; Akcay, A.; Yigitoglu, R.; Covic, A. Effect of treatment of hyperuricemia with allopurinol on blood pressure, creatinine clearence, and proteinuria in patients with normal renal functions. Int. Urol. Nephrol., 2007, 39(4), 1227-1233.

[121] Talaat, K.M.; el-Sheikh, A.R. The effect of mild hyperuricemia on urinary transforming growth factor beta and the progression of chronic kidney disease. Am. J. Nephrol., 2007, 27(5), 435-440.

[122] Siu, Y.P.; Leung, K.T.; Tong, M.K.; Kwan, T.H. Use of allopurinol in slowing the progression of renal disease through its ability to lower serum uric acid level. Am. J. Kidney Dis., 2006, 47(1), 51-59.

[123] Weimert, N.A.; Tanke, W.F.; Sims, J.J. Allopurinol as a cardioprotectant during coronary artery bypass graft surgery. Ann. Pharmacother., 2003, 37(11), 1708-1711.

[124] Hare, J.M.; Mangal, B.; Brown, J.; Fisher, C., Jr.; Freudenberger, R.; Colucci, W.S.; Mann, D.L.; Liu, P.; Givertz, M.M.; Schwarz, R.P. Impact of oxypurinol in patients with symptomatic heart failure. Results of the OPT-CHF study. J. Am. Coll. Cardiol., 2008 51(24), 2301-2309.

[125] Waring, W.S.; McKnight, J.A.; Webb, D.J.; Maxwell, S.R. Lowering serum urate does not improve endothelial function in patients with type 2 diabetes. Diabetologia, 2007, 50(12), 2572-2579.

[126] Daskalopoulou, S.S.; Tzovaras, V.; Mikhailidis, D.P.; Elisaf, M. Effect on serum uric acid levels of drugs prescribed for indications other than treating hyperuricaemia. Curr. Pharm. Des., 2005 , 11(32), 4161-4175.

[127] Athyros, V.G.; Elisaf, M.; Papageorgiou, A.A.; Symeonidis, A.N.; Pehlivanidis, A.N.; Bouloukos, V.I.; Milionis, H.J.; Mikhailidis, D.P. Effect of statins versus untreated dyslipidemia on serum uric acid le vels in patients with coronary heart disease: a subgroup analysis of the GREek Atorvastatin and Coronary-heart-disease Evaluation (GREACE) study. Am. J. Kidney Dis., 2004, 43(4), 589599. 